CLINICAL STUDY

\title{
Acylated ghrelin as a provocative test for the diagnosis of GH deficiency in adults
}

Valentina Gasco, Guglielmo Beccuti, Chiara Baldini, Nunzia Prencipe, Stellina Di Giacomo, Alessandro Berton, Federica Guaraldi, Isabella Tabaro, Mauro Maccario, Ezio Ghigo and Silvia Grottoli

Division of Endocrinology and Metabolism, Department of Medical Science, University of Turin, Turin, Italy

(Correspondence should be addressed to E Ghigo who is now at Divisione di Endocrinologia, Diabetologia e Metabolismo, Dipartimento di Scienze Mediche, ASOU 'Città della Salute e della Scienza' di Torino, C.so Dogliotti 14, 10126 Torino, Italy; Email: ezio.ghigo@unito.it)

\begin{abstract}
Objective: Insulin tolerance test (ITT) is the test of reference for the diagnosis of adult GH deficiency (GHD), although GHRH in combination with arginine (ARG) or GH secretagogues are considered equally reliable tests. Testing with GH secretagogue alone is, anyway, a potent stimulus exploring the integrity of hypothalamic pathways controlling somatotropic function. We therefore aimed to determine the diagnostic reliability of testing with ghrelin, the natural GH secretagogue.

Methods: We studied the GH response (every $15 \mathrm{~min}$ from -15 to $+120 \mathrm{~min}$ ) to acylated ghrelin $(1 \mu \mathrm{g} / \mathrm{kg}$ i.v. at $0 \mathrm{~min})$ in 78 patients with a history of pituitary disease (49 male, 29 female; age (mean \pm s.D.): $52.1 \pm 18.7$ years; BMI: $26.7 \pm 5.3 \mathrm{~kg} / \mathrm{m}^{2}$ ). The lack of $\mathrm{GH}$ response to $\mathrm{GHRH}+\mathrm{ARG}$ and/or ITT was considered the gold standard for the diagnosis of GHD. The best GH cut-off to ghrelin test, defined as the one with the best sensitivity (SE) and specificity (SP), was identified using the receiver-operating characteristic curve analysis.

Results: The best GH cut-off to ghrelin test was $7.3 \mu \mathrm{g} / \mathrm{l}$ in lean subjects (SE 88.2\%, SP 90.9\%), $2.9 \mu \mathrm{g} / \mathrm{l}$ in overweight subjects (SE 92.6\%, SP 100\%) and $0.6 \mu \mathrm{g} / \mathrm{l}$ in obese subjects (SE 50\%, SP 100\%). The diagnostic accuracy was $89.3,94.1$ and $62.5 \%$ respectively.

Conclusions: Our data show that testing with acylated ghrelin represents a reliable diagnostic tool for the diagnosis of adult GHD, in lean and overweight subjects, if appropriate cut-off limits are assumed. Obesity strongly reduces $\mathrm{GH}$ response to ghrelin, GH weight-related cut-off limit and diagnostic reliability of the test.
\end{abstract}

European Journal of Endocrinology 168 23-30

\section{Introduction}

Insulin tolerance test (ITT) is the test of reference for the diagnosis of adult GH deficiency (GHD). At the same time, GHRH in combination with arginine (ARG) or GH secretagogues (GHS) are recognized as equally reliable tests $(1,2,3)$, and glucagon stimulation is considered to be of good diagnostic value $(1,2,3)$. Advantages related to ITT are the possibility to evaluate the complete hypothalamic-pituitary-somatotropic axis (which makes the test useful in patients with both hypothalamic and pituitary diseases) and, concomitantly, explore the adrenocorticotrophin axis, through the induction of hypoglycemia. At the same time, the induced hypoglycemia contraindicates the test in patients with coronary or cerebrovascular disease, a history of ischaemic heart disease or any convulsive disease, and deserves particular attention for the elderly (4). Another limitation related to the test is the need for multiple blood samples, which requires close monitoring of patients for some hours in a specialized investigation unit. Finally, historically, it was reported that ITT has low reproducibility $(5,6,7)$ since false positives (low GH response) are recorded even in normal subjects (NS); however, a recent paper did not confirm the low reproducibility of ITT (8).

On the other hand, GHRH + ARG and GHRH + GHRP-6 tests are safe, well tolerated, reproducible and present well-defined cut-off limits and normative BMI-based reference values for maximal somatotropic secretory capacity, which allow the distinction between normal and GHD subjects $(9,10)$. A major limitation of these tests, based on the administration of GHRH, is the risk of missing the diagnosis of GHD of hypothalamic origin $(2,11,12,13,14)$.

It has been suggested that, as for ITT, testing with GHS alone would represent a potent stimulus that is able to explore also the integrity of hypothalamic pathways controlling somatotropic function (1). GHS are synthetic secretagogues (15) that elicit a dosedependent GH release by binding to a specific receptor, mostly distributed at the hypothalamic level, whose natural ligand is ghrelin (16). Ghrelin is a 28 -amino acid peptide circulating both in acylated and unacylated 
form, the former being a potent stimulator of somatotropic secretion $(16,17)$, in humans more so than in animals $(16,18)$. Ghrelin exerts a strong and dosedependent GH-releasing effect (19) that potentially includes activity at the pituitary and/or hypothalamus. The effect of ghrelin in vivo is stronger than in vitro (19), and it is dependent on the presence of GHRH $(18,19$, $20,21)$. Moreover, ghrelin shows an additive or even synergistic effect on GHRH-stimulated GH release (18) and prevents cyclic refractoriness to GHRH (19). In addition, ghrelin-mediated GH secretion is reduced, although not completely abolished, in animals and patients with lesions of the pituitary stalk, suggesting that the main action of ghrelin occurs at the hypothalamic level $(20,21)$.

Ghrelin and synthetic GHS induce remarkable GH discharge in elderly subjects, although age is associated with a significant decrease in the GH-releasing action of ghrelin and synthetic GH (22).

Testing with acylated ghrelin, as well as with GHS alone, has been proposed for the diagnosis of $\mathrm{GH}$ insufficiency $(23,24,25)$.

In order to define the diagnostic value of testing with ghrelin alone, we studied the GH response to acylated ghrelin in patients with a history of pituitary disease. The lack of GH response to GHRH + ARG and/or ITT was considered as the diagnostic gold standard. We also tried to identify the best GH cut-off to ghrelin test, defined as the one with the best sensitivity (SE) and specificity (SP).

\section{Materials and methods}

We studied the GH response (every $15 \mathrm{~min}$ from -15 to $+120 \mathrm{~min})$ to acylated ghrelin $(1 \mu \mathrm{g} / \mathrm{kg}$ i.v. at $0 \mathrm{~min})$ in 78 patients with a history of pituitary disease (49 male, 29 female; age (mean \pm s.D.): $52.1 \pm 18.7$ years; BMI: $26.7 \pm 5.3 \mathrm{~kg} / \mathrm{m}^{2}$ ). The patients' clinical characteristics are reported in Table 1 .

All patients were also tested with GHRH $(1 \mu \mathrm{g} / \mathrm{kg}$ i.v. at $0 \mathrm{~min})+\mathrm{ARG}(0.5 \mathrm{~g} / \mathrm{kg}$ injected i.v. from 0 to $+30 \mathrm{~min}$ ) (sampling every $15 \mathrm{~min}$ from +30 to $+60 \mathrm{~min}$ ); 25 patients (16 male, nine female; age: $37.1 \pm 14.7$ years; BMI: $26.1 \pm 5.9 \mathrm{~kg} / \mathrm{m}^{2}$ ) also underwent ITT $(0.1-0.15 \mathrm{UI} / \mathrm{kg}$ regular insulin injected i.v. at $0 \mathrm{~min}$ ) (sampling every $15 \mathrm{~min}$ from 0 to $+90 \mathrm{~min}$ ).

$\mathrm{GH}$ responses to these stimuli in the 78 patients were compared with those recorded in an age-matched group of 39 NS (25 male, 14 female; age: $41.4 \pm 23.1$ years; BMI: $23.9 \pm 4.2 \mathrm{~kg} / \mathrm{m}^{2}$ ). IGF1 and IGBP 3 levels were measured and glucose levels recorded during the ITT in all patients and NS. All subjects underwent the three testing sessions in random order and at least 3 days apart. All subjects gave their informed consent to participate in the study, approved by an independent ethical committee.
Table 1 Clinical characteristics of the 78 patients with a history of hypothalamic-pituitary disease.

\begin{tabular}{ll}
\hline Number of males/females (\%) & $49 / 29(62.8 / 37.2)$ \\
Mean age ( \pm s.D.) (years) & $52.1( \pm 18.7)$ \\
Mean BMI ( \pm s.D.) $\left(\mathrm{kg} / \mathrm{m}^{2}\right)$ & $26.7( \pm 5.3)$ \\
Patients with/without other pituitary & $54 / 24$ \\
deficiencies (except GHD) (no.) & \\
Hypothalamic-pituitary disease (\%) & $78(100 \%)$ \\
Pituitary lesion & $59(75.6 \%)$ \\
Primary+secondary (due to Sheehan's & $6+1(9 \%)$ \\
syndrome) empty sella & $7(9 \%)$ \\
Idiopathic & $4(5.1 \%)$ \\
Pituitary hypoplasia & $1(1.3 \%)$ \\
Traumatic brain injury & $59(100 \%)$ \\
Type of treatment for pituitary lesion $(\%)$ & $44(74.6 \%)$ \\
Neurosurgery & $4(6.8 \%)$ \\
Neurosurgery + radiotherapy & $11(18.6 \%)$ \\
None & \\
\hline
\end{tabular}

Serum GH levels $(\mu \mathrm{g} / \mathrm{l})$ were measured in duplicate by the IRMA method (hGH-CTK IRMA; DIASORIN Biomedica, Saluggia, Italy) as reported previously (9). The SE of the assay was $0.04 \mu \mathrm{g} / \mathrm{l}$. The inter- and intraassay coefficients of variation (CV) were 8.6-12.3 and $4.2-6.2 \%$ respectively.

Serum IGF1 levels $(\mu \mathrm{g} / \mathrm{l})$ were measured in duplicate by the RIA method (DIAsource ImmunoAssays, Nivelles, Belgium) after acid-ethanol extraction to avoid interference by binding proteins. The SE of the method was $0.3 \mu \mathrm{g} / \mathrm{l}$. The inter- and intra-assay $\mathrm{CV}$ were $10-12.6$ and $3.8-13.9 \%$ respectively.

Serum IGFBP3 levels $(\mu \mathrm{g} / \mathrm{ml})$ were measured in duplicate by the IRMA method (Immunodiagnostic System, Boldon, UK). The SE of the assay was $0.05 \mu \mathrm{g} / \mathrm{ml}$. The inter- and intra-assay $\mathrm{CV}$ were $6.3-12.4$ and $4.85-9.65 \%$ respectively.

Plasma glucose levels $(\mathrm{mg} / \mathrm{dl})$ were measured by the gluco-oxidase colorimetric method (GLUCOFIX; Menarini Diagnostici, Florence, Italy).

All samples from an individual subject were analysed together.

The results are expressed as mean \pm s.D. Statistical analysis was performed using the Friedman ANOVA and Kendall's concordance test and Wilcoxon matchedpairs test in order to compare multiple and two dependent samples respectively. Kruskal-Wallis ANOVA and Mann-Whitney $U$ test were applied to compare multiple and independent samples respectively. The correlation between variables was sought to calculate the Spearman coefficient.

We tried to identify the best GH cut-off to ghrelin test for the diagnosis of GHD using the receiver-operating characteristic curve (ROC) analysis. These curves were drawn by plotting the SE against the complement of SP (1-SP) for varying cut-off levels of ghrelin-mediated GH peaks. Each point of the ROC curves represents a $\mathrm{SE} / \mathrm{SP}$ pair corresponding to a particular decision threshold. The area under the ROC curve (ROC AUC) represents the probability of correctly distinguishing between the affected and non-affected individuals. The 
perfect diagnostic test has a ROC curve that passes through the upper left-hand corner $(\mathrm{AUC}=1)$, being the true-positive fraction 1.0 or $100 \%$ (perfect SE) and the false-positive fraction 0 (perfect SP). Tests with an AUC under 0.5 do not discriminate between the affected and non-affected subjects (26). The best cut-off in a ROC curve is the closest point to that with the theoretical maximum of both SE and SP (i.e. the point where the curves of SE and SP as a function of the cut-off intersect). The diagnostic cut-off points were calculated for the lean (BMI $<25 \mathrm{~kg} / \mathrm{m}^{2}$ ), overweight (BMI $25-29.9 \mathrm{~kg} / \mathrm{m}^{2}$ ) and obese (BMI $\geq 30 \mathrm{~kg} / \mathrm{m}^{2}$ ) groups.

The lack of $\mathrm{GH}$ response to $\mathrm{GHRH}+\mathrm{ARG}$ and/or ITT was assumed as the gold standard for the diagnosis of GHD. Thus, according to GHD diagnosis guidelines (1, 2, 3), GHD was defined by GHRH+ARG using the BMI cut-offs (i.e. GH peak $\leq 11.0 \mu \mathrm{g} / \mathrm{l}$ in lean subjects, $\leq 8.0 \mu \mathrm{g} / \mathrm{l}$ in overweight subjects and $\leq 4.0 \mu \mathrm{g} / \mathrm{l}$ in obese subjects) and/or by ITT using a GH peak $\leq 3.0 \mu \mathrm{g} / \mathrm{l}$.

SE and SP were calculated using the number of patients with true-positive (TP), true-negative (TN), false-positive (FP) and false-negative (FN) results. SE (calculated as $\mathrm{TP} /(\mathrm{TP}+\mathrm{FN})$ ) was defined as the percentage of GHD patients who had a peak $\mathrm{GH}$ value below the specific BMI-related cut-off point; SP (calculated as $\mathrm{TN} /(\mathrm{TN}+\mathrm{FP})$ ) was defined as the percentage of non-GHD patients who had a peak GH value above the specific BMI-related cut-off point.

The positive predictive value (PPV) (calculated as $\mathrm{TP} /(\mathrm{TP}+\mathrm{FP}))$ was defined as the percentage of patients with a peak $\mathrm{GH}$ value below the specific BMI-related cut-off point that was really GHD, while the negative predictive value (NPV) (calculated as $\mathrm{TN} /(\mathrm{TN}+\mathrm{FN})$ ) was defined as the percentage of patients with a peak $\mathrm{GH}$ value above the specific BMI-related cut-off point that was not really GHD.

The positive likelihood ratio $(\mathrm{LHR}+)$ (calculated as $\mathrm{SE} /(100-\mathrm{SP}))$ was defined as the probability of a person who has the disease testing positive divided by the probability of a person who does not have the disease testing positive.

The negative likelihood ratio $(\mathrm{LHR}-)$ (calculated as $(100-\mathrm{SE}) / \mathrm{SP})$ was defined as the probability of a person who has the disease testing negative divided by the probability of a person who does not have the disease testing negative.

A LHR $+>1$ indicates that a positive result to the test is associated with the disease. A LHR $-<1$ indicates that a negative result to the test is associated with the absence of the disease. Tests where the likelihood ratios lie close to 1 have little practical significance, as the post-test probability (odds) is little different from the pretest probability and, as such, is used primarily for diagnostic purposes and not for screening purposes. If the LHR + is $>5$ or the LHR - is $<0.2$ (i.e. 1/5), then they can be applied to the pre-test probability of a patient having the disease tested for to estimate a posttest probability of the disease state existing (27).
The accuracy of the test was defined as the probability of a person who has the disease and of a person who does not have the disease testing positive and negative, respectively, and calculated as $(\mathrm{VP}+\mathrm{VN}) /$ total.

\section{Results}

Based on the $\mathrm{GH}$ response to $\mathrm{GHRH}+\mathrm{ARG}$ and/or ITT, patients were distinguished into patients with GHD (GHD: 56; 39 male, 17 female) and without GHD (non-GHD: 22; ten male, 12 female). The two groups did not differ for age and BMI (age GHD vs non-GHD: 51.9 \pm 17.9 vs $52.6 \pm 16.1$ years; BMI GHD vs non-GHD: $27.3 \pm 4.5$ vs $24.6 \pm 5.6 \mathrm{~kg} / \mathrm{m}^{2}$ ). Mean age and BMI in NS (age: $41.4 \pm 23.1$ years; BMI: $22.5 \pm 2.1 \mathrm{~kg} / \mathrm{m}^{2}$ ) were similar to those in GHD and non-GHD.

IGF1 levels in GHD were lower than those in nonGHD when expressed both as mean and SDS levels $(91.5 \pm 52.6$ vs $201.2 \pm 54.7 \mu \mathrm{g} / \mathrm{l}, \quad P<0.05 ;-1.0$ \pm 0.8 vs $0.6 \pm 1.2, P<0.05)$; these groups showed a clear overlap (IGF1 range in GHD vs non-GHD: 27-331 vs $108-340 \mu \mathrm{g} / \mathrm{l})$. It should be noted that IGF1 levels in both groups also showed some overlap with IGF1 levels in NS (IGF1 range in NS: 115-357 $\mu \mathrm{g} / \mathrm{l}$ ).

IGFBP3 levels in GHD $(2.1 \pm 1.1 \mu \mathrm{g} / \mathrm{ml})$ were similar to those in non-GHD $(2.8 \pm 1.1 \mu \mathrm{g} / \mathrm{ml})$ with a full overlap between the two groups (IGFBP 3 range in GHD: $4.4-0.5 \mu \mathrm{g} / \mathrm{ml}$ vs IGFBP3 range in non-GHD: $6.1-1.8 \mu \mathrm{g} / \mathrm{ml}$ ) and NS (IGFBP3 range in NS: $4.3-2 \mu \mathrm{g} / \mathrm{ml}$ ).

The GH response to ghrelin in NS $(69.2 \pm 37.8 \mu \mathrm{g} / \mathrm{l})$ was similar to that during $\mathrm{GHRH}+\mathrm{ARG}(63.1$ $\pm 38.2 \mu \mathrm{g} / \mathrm{l})$ and both were higher than that during the ITT $(25.0 \pm 20.0 \mu \mathrm{g} / \mathrm{l}, P<0.05)$ (Fig. 1).

As with NS, the $\mathrm{GH}$ response to ghrelin in non-GHD $(23.9 \pm 21.3 \mu \mathrm{g} / \mathrm{l})$ was similar to that during $\mathrm{GHRH}+$ ARG $(29.7 \pm 18.7 \mu \mathrm{g} / \mathrm{l})$ and both were higher than that during the ITT $(14.1 \pm 12.7 \mu \mathrm{g} / \mathrm{l}, \mathrm{P}<0.05)$ (Fig. 1).

The $\mathrm{GH}$ response to ghrelin in GHD $(4.0 \pm 3.7 \mu \mathrm{g} / \mathrm{l})$ was lower than that during GHRH+ARG (5.1 $\pm 4.1 \mu \mathrm{g} / \mathrm{l}, P<0.05)$ but higher than that elicited by ITT $(1.4 \pm 1.6 \mu \mathrm{g} / \mathrm{l}, \quad P<0.05)$; obviously, the $\mathrm{GH}$ response during $\mathrm{GHRH}+\mathrm{ARG}$ was higher than that during the ITT $(P<0.05)$ (Fig. 1).

The mean GH response to GHRH + ARG in GHD was lower than that recorded in non-GHD $(3.4 \pm 3.1 \mathrm{vs}$ $24.8 \pm 15.4 \mu \mathrm{g} / \mathrm{l}, P<0.05)$, and both were lower than that in NS $(63.1 \pm 38.2 \mu \mathrm{g} / \mathrm{l}, P<0.05)$ (Fig. 1).

Similarly, the mean GH response to ITT in GHD was lower than in non-GHD $(1.1 \pm 1.2$ vs $14.1 \pm 12.7 \mu \mathrm{g} / \mathrm{l}$, $P<0.05)$, and both were lower than that elicited in NS $(25.0 \pm 20.0 \mu \mathrm{g} / \mathrm{l}, P<0.05)$ (Fig. 1). It should be noted that there was no difference between glucose nadir during the ITT in GHD, non-GHD and NS (blood glucose levels: $27.2 \pm 10.2$ vs $27.0 \pm 15.7$ vs 23.9 $\pm 10.4 \mathrm{mg} / \mathrm{dl}$ respectively).

Similarly, the mean GH response to ghrelin in GHD was lower than that in non-GHD $(2.5 \pm 4.1$ vs 23.9 $\pm 21.3 \mu \mathrm{g} / \mathrm{l}, P<0.05)$, and both were lower than that 

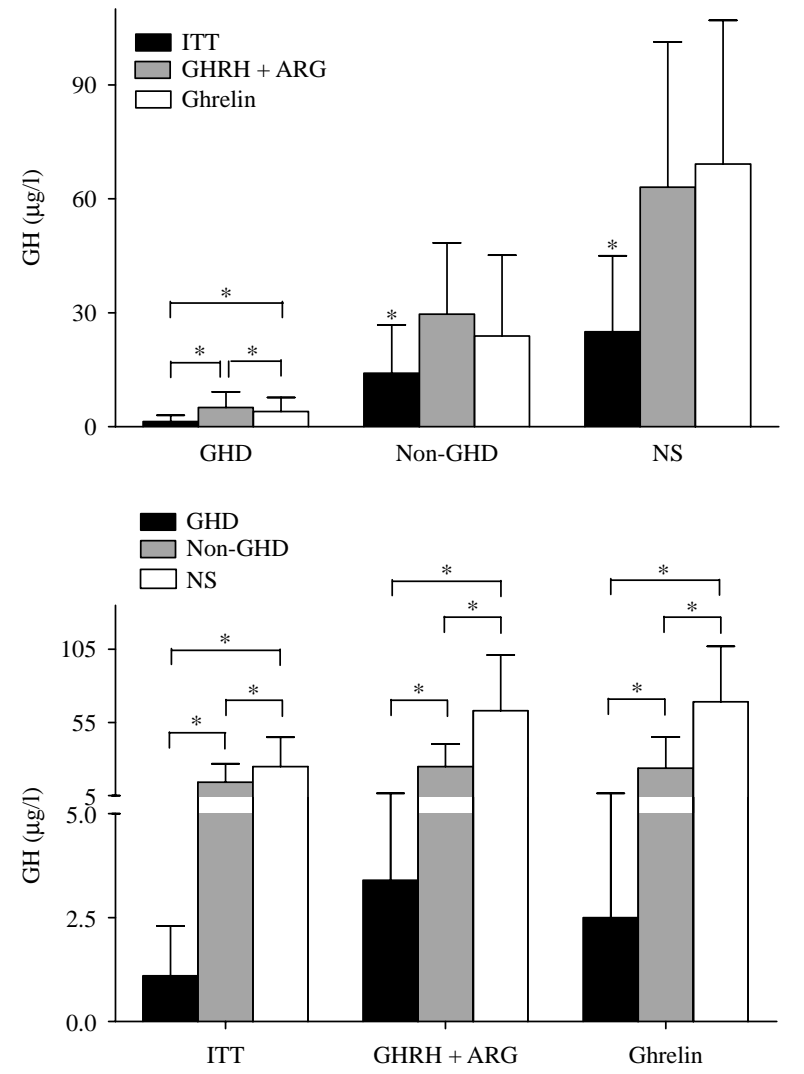

Figure 1 Peak GH response (mean \pm s.D.) to ITT, GHRH + ARG and ghrelin test in patients with GHD (GHD), patients without GHD (non-GHD) and normal subjects (NS) as a function of subjects' group (upper panel) and as a function of type of test (lower panel) $\left({ }^{\star} P<0.05\right)$.

recorded in NS $(69.2 \pm 37.8 \mu \mathrm{g} / \mathrm{l}, \mathrm{P}<0.05)$ (Fig. 1). The GH response to ghrelin was negatively associated with BMI at least in NS $(r=-0.4, P<0.05)$ and in non-GHD $(r=-0.5, P<0.05)$.

The individual peak GH response to ghrelin occurred in all subjects between +15 and +45 min with a curve Cmax at +30 min in GHD and non-GHD similar to NS (Fig. 2).

The best GH cut-offs to ghrelin test were: i) $7.3 \mu \mathrm{g} / \mathrm{l}$ in lean subjects with a SE and SP value of 88.2 and $90.9 \%$ respectively; ii) $2.9 \mu \mathrm{g} / \mathrm{l}$ in overweight subjects with a SE and SP value of 92.6 and 100\% respectively; and iii) $0.6 \mu \mathrm{g} / \mathrm{l}$ in obese subjects with a SE and SP value of 50 and $100 \%$ respectively (Fig. 3).

The PPV, NPV, ROC AUC, LHR +, LHR - and the diagnostic accuracy of ghrelin test of these cut-off limits are reported in Table 2. Thus, in the case of a positive result to ghrelin test, the prediction of GHD was good in lean and overweight subjects (LHR +9.7 and 6.5 respectively), but poor in the obese (LHR +2$)$. Likewise, in the case of a negative result, the prediction of the absence of the disease was good in lean and overweight subjects (LHR -0.1 in both groups), but insufficient in the obese (LHR - 0.67).

\section{Side effects}

Administration of ghrelin did not cause any relevant side effect except for face flushing observed in 12 patients and five NS. A similar effect was observed in 23 patients and 12 NS after GHRH administration. As expected, all subjects developed typical signs and symptoms of hypoglycemia during the ITT.

\section{Discussion}

Our results, based on a considerable group of patients with a history of hypothalamic-pituitary disease, indicate that acylated ghrelin represents a reliable provocative test, alternative to ITT or GHRH+ARG, for the diagnosis of severe GHD in adults.

Indeed, our data specifically show that:

a) ghrelin is basically as potent as the GHRH + ARG test in NS but also in non-GHD and GHD; similar to GHRH + ARG, ghrelin alone is a more powerful GH secretagogue than ITT in all groups;

b) as expected, as with the other tests, the mean $\mathrm{GH}$ response to ghrelin progressively decreases from NS to GHD. GH response to ghrelin is negatively associated with BMI, at least in NS and non-GHD;

c) as demonstrated by the ROC curve, when BMIadjusted cut-off limits are applied, ghrelin test presents a good SE and SP, being able to recognize $82.1 \%$ of the patients with severe GHD and $95.5 \%$ of patients without GHD; and

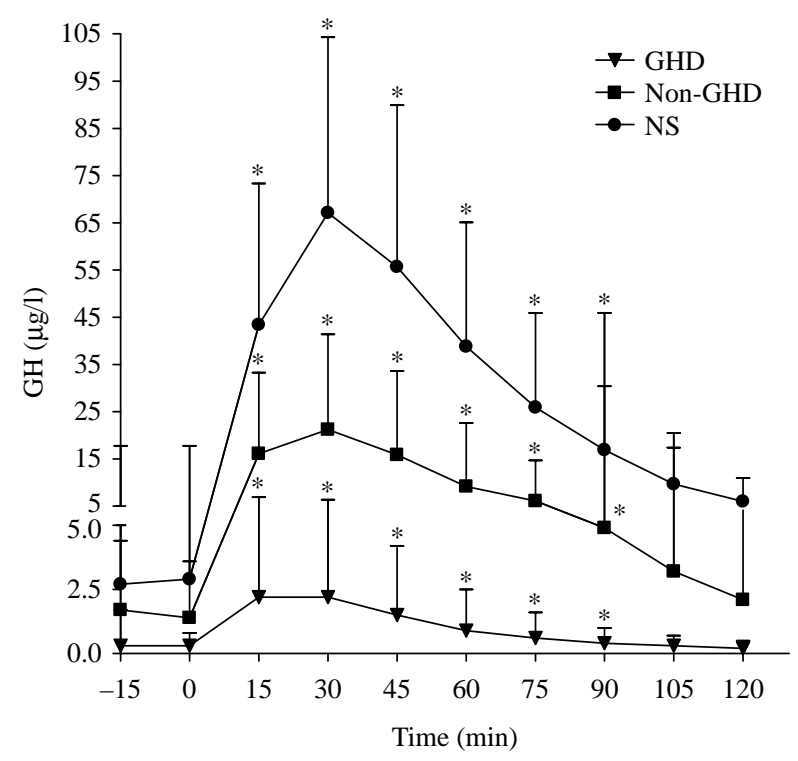

Figure 2 Mean GH (mean \pm s.D.) curve to ghrelin test in patients with GHD (GHD), patients without GHD (non-GHD) and normal subjects (NS) ( ${ }^{*} P<0.05$ vs basal). 

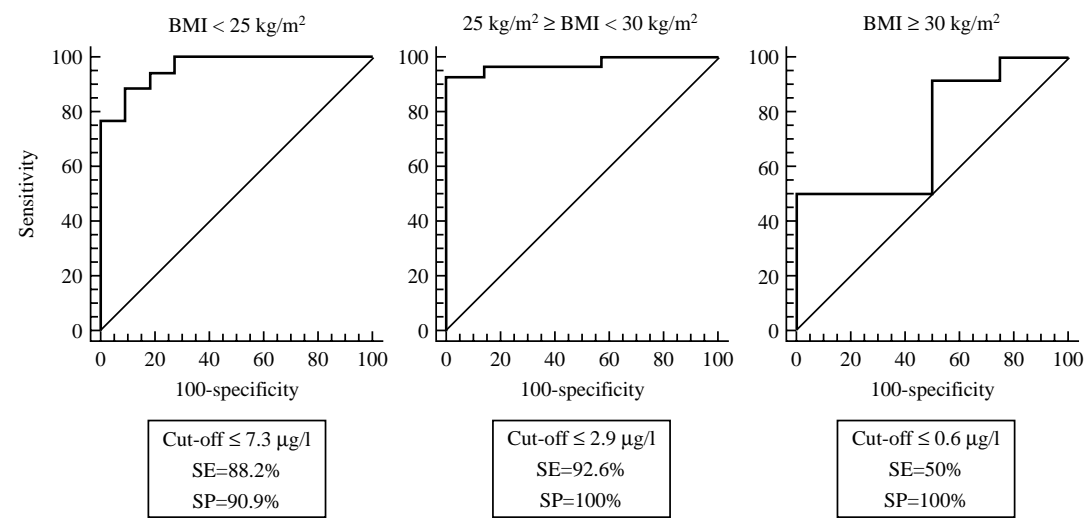

Figure $3 \mathrm{ROC}$ analysis to identify the best GH cut-off to ghrelin test in lean, overweight and obese patients (SE, sensitivity; SP, specificity). d) obesity strongly reduces GH response to ghrelin, its weight-related cut-off limit and its diagnostic reliability.

Previous studies have clearly demonstrated that ghrelin is a potent natural GH secretagogue $(16,18$, $19,20,21,25)$, and that its acute administration induces a strong GH release, similar to that recorded after stimulation with GHRH in combination with ARG, and higher than that provoked by insulin-induced hypoglycemia (25). The present study confirms that ghrelin's effect is equal to GHRH+ARG and stronger than ITT both in non-GHD and GHD. The strong GH-releasing effect of ghrelin, as well as of several synthetic GHS, has been explained by the dual action exerted mostly at the hypothalamic level, but also on the pituitary $(19,20,21)$. Indeed, ghrelin seems to be able to trigger hypothalamic GHRH activity, and activate GHS receptor in the pituitary, counteracting somatostatin's inhibitory action (28).

As expected and as with the other tests, GH response to ghrelin is strongly reduced in GHD, in agreement with previous studies with ghrelin or GHRP-2 $(23,25)$. In our experience, in GHD, GH response to ghrelin is more impaired than the response to GHRH + ARG, at variance with that reported by Aimaretti et al. (25) who, however, did not use weight-related cut-offs for the GHRH + ARG test.

Moreover, we showed that the mean GH response to different stimuli is lower in patients with a history of hypothalamic-pituitary disease but, otherwise, GH sufficient in comparison with NS. To explain this difference some hypothalamic-pituitary alterations reflecting previous neurosurgery and/or radiotherapy can be hypothesized. Moreover, this picture has also been reported by other authors $(8,29)$ even in patients with non-functioning microadenomas never exposed to either previous neurosurgery and/or radiotherapy (29). It is a matter of debate whether this group of patients can be classified as having 'partial' GHD. It remains that the clinical diagnosis has to be done on an individual basis and patients showing a GH response within the normal limits have to be considered as normal; an appropriate follow-up over time would be recommended in these cases.

Our study also clearly demonstrates a negative association between GH response to ghrelin and BMI. The negative influence of adiposity on spontaneous and stimulated GH secretion had already been clearly demonstrated many years ago $(30,31,32,33,34,35)$. Impaired GH secretion in obesity could be due to neuroendocrine (endogenous GHRH hypoactivity and/or somatostatinergic hyperactivity) or metabolic alterations (chronically elevated FFA levels, hyperinsulinism) (30, 31, 32, 33, 34, 35). Independently from the pathophysiological explanation of GH insufficiency in obesity, the clear, progressive reduction of $\mathrm{GH}$ response to any provocative tests, including ghrelin, has clinical implications when these stimuli are used to prove GHD (34).

Table 2 Sensibility (SE), specificity (SP), positive predictive value (PPV), negative predictive value (NPV), area under the ROC curve (ROC $A U C)$, positive likelihood ratio (LHR +), negative likelihood ratio (LHR-) and the diagnostic accuracy of cut-off limits to ghrelin test identified with the ROC analysis in lean, overweight and obese patients.

\begin{tabular}{|c|c|c|c|c|c|c|c|c|}
\hline & SE (\%) & SP $(\%)$ & PPV (\%) & NPV (\%) & ROC AUC & LHR + & LHR - & $\begin{array}{c}\text { Diagnostic } \\
\text { accuracy (\%) }\end{array}$ \\
\hline $\mathrm{GH} \leq 7.3 \mu \mathrm{g} / \mathrm{l}$ in lean subjects & 88.2 & 90.9 & 93.6 & 83.3 & 0.9 & 9.7 & 0.1 & 89.3 \\
\hline $\mathrm{GH} \leq 2.9 \mu \mathrm{g} / \mathrm{l}$ in overweight subjects & 92.6 & 100 & 100 & 77.8 & 0.9 & 6.5 & 0.1 & 94.1 \\
\hline $\mathrm{GH} \leq 0.6 \mu \mathrm{g} / \mathrm{l}$ in obese subjects & 50 & 100 & 100 & 40 & 0.7 & 2 & 0.7 & 62.5 \\
\hline
\end{tabular}


The primary aim of the study was to determine whether testing with acylated ghrelin (the only form of ghrelin that is able to stimulate somatotropic secretion (36)) alone represents a reliable alternative provocative stimulus for the diagnosis of adult GHD. In theory, the availability of such a potent test, active both at the hypothalamic and pituitary levels, would be advantageous over a provocative stimulus like GHRH + ARG that is extremely potent, shows excellent SP, but mainly acts at the pituitary level and, for this reason, is associated with the risk of $\mathrm{FN}$ response in patients with GHD due to hypothalamic derangement $(2,11,12,13,14)$. Except for our study, no normative data about $\mathrm{GH}$ response to acylated ghrelin have been reported.

As demonstrated by the ROC curve, the proposed cutoff limits of reference for ghrelin test are characterized by a good SE and SP, at least in lean and overweight patients, being able to identify 46 out of $56(82.1 \%)$ patients with severe GHD and 21 out of $22(95.5 \%)$ patients without GHD.

The usefulness of the ghrelin test in lean and overweight subjects is also supported by the good $\mathrm{LHR}+(>5)$ and LHR $-(<0.2)$ of the identified cutoffs (27). It should be noted that the ROC AUC is close to 1 , suggesting the excellent informativity of the test.

Our data strongly suggest ghrelin test to be a reliable tool for the diagnosis of adult GHD, and can be used alternatively to ITT and GHRH + ARG, which have been used herein $(1,2,3)$. However, attention has to be paid to the confounding effect of overweight and obesity on the interpretation of $\mathrm{GH}$ response to this provocative test. As previously mentioned, obesity impairs GH response to any provocative test $(30,31,32,33,34,35)$, including ghrelin (37). Consequently, appropriate BMI-dependent cut-offs are mandatory, in order to avoid FP diagnosis of severe GHD in obese adults. It should also be noted that whenever normative data for a provocative test are generated including obese among NS, the risk of FN diagnosis in lean GHD patients would be considerable.

Actually, the impact of obesity on GH response to ghrelin seems to be particularly critical. Indeed, the cutoff limits in obese subjects were so low that diagnostic SE of the ghrelin test was considerably impaired, compared with lean and overweight subjects. Moreover, it must be underlined that there was a good diagnostic accuracy of the cut-off to ghrelin test in lean $(89.3 \%)$ and overweight (94.1\%) subjects, while the cut-off in obese subjects showed a poor diagnostic accuracy $(62.5 \%)$. Thus, ghrelin test is unlikely to be the first choice as a diagnostic tool in obese patients suspected for GHD; in these patients, ITT and GHRH+ARG remains the preferable ones.

At the same time, ghrelin test shows a very good safety profile and has no contraindications, at variance with ITT that is contraindicated in patients with coronary or cerebrovascular disease, a history of ischaemic heart disease or any convulsive disease, and deserves particular attention for the elderly $(1,2,3)$. Moreover, because the peak $\mathrm{GH}$ response invariably occurred between 15 and 45 min after ghrelin administration in all studied subjects, it would probably be possible to shorten the testing procedure, leaving only three samples performed at $+15,30$ and $45 \mathrm{~min}$.

We did not assess the intra-individual reproducibility of $\mathrm{GH}$ response to ghrelin. However, a previous study performed in young healthy volunteers demonstrated a good intra-individual reproducibility (18).

In conclusion, our study shows that acylated ghrelin is a reliable test for the diagnosis of adult GHD, at least in lean and overweight subjects, provided that appropriate cut-off limits are assumed. Indeed, obesity strongly reduces GH response to ghrelin, its weight-related cut-off limit and its diagnostic reliability.

\section{Declaration of interest}

The authors declare that there is no conflict of interest that could be perceived as prejudicing the impartiality of the research reported.

\section{Funding}

The present study was supported by the University of Turin and the SMEM Foundation.

\section{References}

1 Ho KK. Consensus guidelines for the diagnosis and treatment of adults with GH deficiency II: a statement of the GH Research Society in association with the European Society for Pediatric Endocrinology, Lawson Wilkins Society, European Society of Endocrinology, Japan Endocrine Society, and Endocrine Society of Australia. European Journal of Endocrinology 2007157 695-700. (doi:10.1530/EJE-07-0631)

2 Molitch ME, Clemmons DR, Malozowski S, Merriam GR \& Vance ML. Evaluation and treatment of adult growth hormone deficiency: an Endocrine Society clinical practice guideline. Journal of Clinical Endocrinology and Metabolism 201196 1587-1609. (doi:10.1210/ jc. 2011-0179)

3 Cook DM, Yuen KC, Biller BM, Kemp SF \& Vance ML. American Association of Clinical Endocrinologists medical guidelines for clinical practice for growth hormone use in growth hormonedeficient adults and transition patients - 2009 update. Endocrine Practice 200915 (Suppl 2) 1-29.

4 Jones SL, Trainer PJ, Perry L, Wass JA, Besser GM \& Grossman A. An audit of the insulin tolerance test in adult subjects in an acute investigation unit over one year. Clinical Endocrinology $1994 \mathbf{4 1}$ 123-128. (doi:10.1111/j.1365-2265.1994.tb03793.x)

5 Hoeck HC, Vestergaard P, Jacobsen PE \& Laurberg P. Test of growth hormone secretion in adults: poor reproducibility of the insulin tolerance test. European Journal of Endocrinology 1995133 305-312. (doi:10.1530/eje.0.1330305)

6 Fisker S, Jorgenen JO, Orskov H \& Christiansen JS. L-arginine and insulin tolerance tests in the diagnosis of adult growth hormone deficiency: influence of confounding factors. Clinical Endocrinology 199848 109-115. (doi:10.1046/j.1365-2265.1998.00362.x)

7 Vestergaard P, Hoeck HC, Jakobsen PE \& Laurberg PR. Reproducibility of growth hormone and cortisol response to the insulin tolerance test and the short ACTH test in normal adults. Hormone and Metabolic Research 199729 106-110. (doi:10.1055/s-2007979000) 
8 Chanson P, Cailleux-Bounacer A, Kuhn JM, Weryha G, Chabre O, Borson-Chazot F, Dubois S, Vincent-Dejean C, Brue T, Fedou C et al. Comparative validation of the growth hormone-releasing hormone and arginine test for the diagnosis of adult growth hormone deficiency using a growth hormone assay conforming to recent international recommendations. Journal of Clinical Endocrinology and Metabolism 201095 3684-3692. (doi:10.1210/jc.20100295)

9 Corneli G, Di Somma C, Baldelli R, Rovere S, Gasco V, Croce CG, Grottoli S, Maccario M, Colao A, Lombardi G et al. The cut-off limits of the GH response to GH-releasing hormone-arginine test related to body mass index. European Journal of Endocrinology 2005153 257-264. (doi:10.1530/eje.1.01967)

10 Kelestimur F, Popovic V, Leal A, Van Dam PS, Torres E, Perez Mendez LF, Greenman Y, Koppeschaar HPF, Dieguez C \& Casanueva FF. Effect of obesity and morbid obesity on the growth hormone (GH) secretion elicited by the combined GHRH + GHRP-6 test. Clinical Endocrinology $2006 \mathbf{6 4}$ 667-671. (doi:10.1111/j. 1365-2265.2006.02525.x)

11 Darzy KH, Aimaretti G, Wieringa G, Gattamaneni HR, Ghigo E \& Shalet SM. The usefulness of the combined growth hormone (GH)releasing hormone and arginine stimulation test in the diagnosis of radiation-induced $\mathrm{GH}$ deficiency is dependent on the postirradiation time interval. Journal of Clinical Endocrinology and Metabolism 200388 95-102. (doi:10.1210/jc.2002-021094)

12 Ham JN, Ginsberg JP, Hendell CD \& Moshang T. Growth hormone releasing hormone plus arginine stimulation testing in young adults treated in childhood with cranio spinal radiation therapy. Clinical Endocrinology 200562 628-632. (doi:10.1111/j.13652265.2005.02272.x)

13 Bjork J, Link K \& Erfurth EM. The utility of the growth hormone (GH) releasing hormone-arginine test for diagnosing $\mathrm{GH}$ deficiency in adults with childhood acute lymphoblastic leukemia treated with cranial irradiation. Journal of Clinical Endocrinology and Metabolism 200590 6048-6054. (doi:10.1210/jc.20050304)

14 Maghnie M, Cavigioli F, Tinelli C, Autelli M, Aricò M, Aimaretti G \& Ghigo E. GHRH plus arginine in the diagnosis of acquired GH deficiency of childhood onset. Journal of Clinical Endocrinology and Metabolism 200287 2740-2744. (doi:10. $1210 /$ jc. 87.6.2740)

15 Bowers CY. Synergistic release of growth hormone by GHRP and GHRH: scope and implication. In Growth Hormone Secretagogues in Clinical Practice, pp 1-25. Eds BB Bercu \& RF Walker. New York: Marcel Dekker, 1998.

16 Kojima M, Hosoda H, Date $\mathrm{Y}$, Nakazato M, Matsuo H \& Kangawa K. Ghrelin is a growth-hormone-releasing acylated peptide from stomach. Nature 1999402 656-660. (doi:10.1038/ 45230)

17 Horvath TL, Diano S, Sotonyi P, Heiman M \& Tschöp M. Ghrelin and the regulation of energy homeostasis: a hypothalamic perspective. Endocrinology $2001 \mathbf{1 4 2}$ 4163-4169. (doi:10. 1210/en.142.10.4163)

18 Arvat E, Maccario M, Di Vito L, Broglio F, Benso A, Gottero C, Papotti M, Muccioli G, Dieguez C, Casanueva FF et al. Endocrine activities of ghrelin, a natural growth hormone secretagogue (GHS), in humans: comparison and interactions with hexarelin, a nonnatural peptidyl GHS, and GH-releasing hormone. Journal of Clinical Endocrinology and Metabolism 200186 1169-1174. (doi:10.1210/jc.86.3.1169)

19 van der Lely AJ, Tschöp M, Heiman ML \& Ghigo E. Biological, physiological, pathophysiological, and pharmacological aspects of ghrelin. Endocrine Reviews 200425 426-457. (doi:10.1210/er. 2002-0029)

20 Popovic V, Miljic D, Micic D, Damjanovic S, Arvat E, Ghigo E, Dieguez C \& Casanueva FF. Ghrelin main action on the regulation of growth hormone release is exerted at hypothalamic level. Journal of Clinical Endocrinology and Metabolism $2003 \mathbf{8 8}$ 3450-3453. (doi:10.1210/jc.2003-030211)

21 Maghnie M, Pennati MC, Civardi E, Di Iorgi N, Aimaretti G, Foschini ML, Corneli G, Tinelli C, Ghigo E, Lorini R et al. GH response to ghrelin in subjects with congenital GH deficiency: evidence that ghrelin action requires hypothalamic-pituitary connections. European Journal of Endocrinology $2007 \mathbf{1 5 6}$ 449-454. (doi:10.1530/EJE-06-0642)

22 Broglio F, Benso A, Castiglioni C, Gottero C, Prodam F, Destefanis S, Gauna C, van der Lely AJ, Deghenghi R, Bo M et al. The endocrine response to ghrelin as a function of gender in humans in young and elderly subjects. Journal of Clinical Endocrinology and Metabolism 200388 1537-1542. (doi:10.1210/jc.2002021504)

23 Chihara K, Shimatsu A, Hizuka N, Tanaka T, Seino Y, Kato Y \& for the KP-102 Study Group. A simple diagnostic test using GH-releasing peptide-2 in adult GH deficiency. European Journal of Endocrinology 2007157 19-27. (doi:10.1530/EJE-07-0066)

24 Petersenn S, Jung R \& Beil FU. Diagnosis of growth hormone deficiency in adults by testing with GHRP-6 alone or in combination with GHRH: comparison with the insulin tolerance test. European Journal of Endocrinology 2002146 667-672. (doi:10.1530/eje.0.1460667)

25 Aimaretti G, Baffoni C, Broglio F, Janssen JAM, Corneli G, Deghenghi R, van der Lely AJ, Ghigo E \& Arvat E. Endocrine responses to ghrelin in adult patients with isolated childhoodonset growth hormone deficiency. Clinical Endocrinology 200256 765-771. (doi:10.1046/j.1365-2265.2002.01547.x)

26 Zweig MH \& Campbell G. Receiver-operating characteristic (ROC) plots: a fundamental evaluation tool in clinical medicine. Clinical Chemistry 199339 561-577.

27 Beardsell I, Hubert D, Robinson S, Bell S \& Rumbold H. MCEM Part A: MCQs. Royal Society of Medicine Pr Ltd, 2009.

28 Tannenbaum GS, Epelbaum J \& Bowers CY. Interrelationship between the novel peptide ghrelin and somatostatin/growth hormone-releasing hormone in regulation of pulsatile growth hormone secretion. Endocrinology 2003144 967-974. (doi:10. 1210/en.2002-220852)

29 Yuen KCJ, Cook DM, Sahasranam P, Patel P, Ghods DE, Shahinian HK \& Friedman TC. Prevalence of GH and other anterior pituitary hormone deficiencies in adults with nonsecreting pituitary microadenomas and normal serum IGF-1 levels. Clinical Endocrinology 200869 292-298. (doi:10.1111/j.13652265.2008.03201.x)

30 Ghigo E, Procopio M, Boffano GM, Arvat E, Valente F, Maccario M, Mazza E \& Camanni F. Arginine potentiates but does not restore the blunted growth hormone response to growth hormonereleasing hormone in obesity. Metabolism 199241 560-563. (doi:10.1016/0026-0495(92)90220-5)

31 Procopio M, Maccario M, Grottoli S, Oleandri SE, Boffano GM, Camanni F \& Ghigo E. Short-term fasting in obesity fails to restore the blunted $\mathrm{GH}$ responsiveness to $\mathrm{GH}$-releasing hormone alone or combined with arginine. Clinical Endocrinology 199543 665-669. (doi:10.1111/j.1365-2265.1995.tb00532.x)

32 Maccario M, Valetto MR, Savio P, Aimaretti G, Baffoni C, Procopio M, Grottoli S, Oleandri SE, Arvat E \& Ghigo E. Maximal secretory capacity of somatotrope cells in obesity: comparison with GH deficiency. International Journal of Obesity and Related Metabolic Disorders 199721 27-32. (doi:10.1038/sj.ijo. 0800356)

33 Maccario M, Gauna C, Procopio M, Di Vito L, Rossetto R, Oleandri SE, Grottoli S, Ganzaroli C, Aimaretti G \& Ghigo E. Assessment of GH/IGF-I axis in obesity by evaluation of IGF-I levels and the GH response to GHRH+arginine test. Journal of Endocrinological Investigation 199922 424-429.

34 Bonert VS, Elashoff JD, Barnett P \& Melmed S. Body mass index determines evoked growth hormone $(\mathrm{GH})$ responsiveness in normal healthy male subjects: diagnostic caveat for adult $\mathrm{GH}$ deficiency. Journal of Clinical Endocrinology and Metabolism 2004 89 3397-3401. (doi:10.1210/jc.2003-032213)

35 Qu XD, Gaw Gonzalo IT, Al Sayed MJ, Cohan P, Christenson PD, Swerdloff RS, Kelly DF \& Wang C. Influence of body mass index and gender or growth hormone (GH) responses to GH-releasing 
hormone plus arginine and insulin tolerance tests. Journal of Clinical Endocrinology and Metabolism 200590 1563-1569. (doi:10.1210/jc.2004-1450)

36 Broglio F, Benso A, Gottero C, Prodam F, Gauna C, Filtri L, Arvat E, van der Lely AJ, Deghenghi R \& Ghigo E. Non-acylated ghrelin does not possess the pituitaric and pancreatic endocrine activity of acylated ghrelin in humans. Journal of Endocrinological Investigation 200326 192-196.

37 Tassone F, Broglio F, Destefanis S, Rovere S, Benso A, Gottero C, Prodam F, Rossetto R, Gauna C, van der Lely AJ et al. Neuroendocrine and metabolic effects of acute ghrelin administration in human obesity. Journal of Clinical Endocrinology and Metabolism $2003 \mathbf{8 8}$ 5478-5483. (doi:10.1210/jc.2003-030564)

Received 6 July 2012

Revised version received 7 October 2012

Accepted 18 October 2012 